\title{
Reproductive biology characteristic of Jatropha curcas (Euphorbiaceae)
}

\author{
Xiu-Rong Wang \& Gui-Jie Ding* \\ College of Forestry, Guizhou University, Guiyang 550025, China; wxr7211@126.com, guijieding@yahoo.com.cn \\ * Corresponding author
}

Received 02-XII-2011. C Corrected 30-IV-2012. Accepted 29-V-2012.

\begin{abstract}
Jatropha curcas belongs to family of Euphorbiaceae, and is an important biological tree species for diesel production. The current descriptions of the phenotypic traits for male and female flowers are not comprehensive and there have been no reports about the process of $J$. curcas from pollen germination on stigma to pollen tubes conducting fertilization after entering the ovary and ovule. To assess this, experiments were undertaken to study the reproductive biology characteristic of $J$. curcas in Guiyang Guizhou Province, China. Floral structure and pollen germination process were described in detail and the breeding system was determined. The results showed that flower of $J$. curcas was both unisexual and monoecious, with a flowering phase between April-November. Both female and male flowers have five petals in contorted arrangement and five calyxes in imbricated arrangement. Female flower originated from bisexual flower finally formed unisexual flowers as the stamen ceased growth in different period. The pistil had 3-5 styles, connected at base and separated into 3-5 stigmas on the top. Each stigma had 2-4 lobes. The styles were hollow. The pollen germinated on the surface of the stigma, is then transported via the vascular tissues, which was arranged in bundles, and finally channeled through the micropyle to enter the blastula. The pollen tube was shaped in a long uneven cylinder. The top end of it became swollen and formed a small round hole for the purpose of releasing sperm nuclei while the pollen tube itself was growing and extending. Estimation of out-crossing index and artificial pollination experiments indicated that $J$. curcas was capable of both self-pollination and cross-pollination. The germination speed of the pollen on the stigma did not differ so much between the one by self-pollination and the one by cross-pollination, and the pollen from the two different sources could both reach the ovary within one day. Both artificial pollination test and out-crossing index have indicated that: $J$. curcas has both self-pollination and cross-pollination systems. Rev. Biol. Trop. 60 (4): 1525-1533. Epub 2012 December 01.
\end{abstract}

Key words: Jatropha curcas, floral structure, artificial pollination, pollen germinate, breeding system.

Jatropha curcas is an important biological tree species for diesel production that belongs to the family of Euphorbiaceae. Low numbers of female flowers in $J$. curcas, less branching and inadequate pollination are the major factors that limit seed production and oil yield of J. curcas (Abdelgadir et al. 2008). Blooming period and the number of level-2 branchs are the two important indexes for $J$. curcas's breeding and cultivation (Xie et al. 2009). In recent years, more research has been done on bloom habits and biological characteristics of pollination in J. curcas (Li et al. 2007, Luo et al. 2007, Abdelgadir et al. 2009). The pistil stigma has the strongest vigorous viability in $1-5 \mathrm{~d}$ after anthesis, and pollen vitality is highest during 0-6h after anthesis and fruit setting is higher in this condition (Bhattacharya et al., 2005, Luo et al. 2007). Both of the fruit set rate are about $90 \%$ of the first and second flowering (Yang et al. 2007). The fruit setting rate of artificial pollination was obviously higher than that of the natural pollination and $J$. curcas is with the tendency of cross-pollination (Yang et al. 2007). Cross-pollinated flowers had significantly higher fruit set than self-pollinated flowers. Flowers exposed to single and multiple visits by honeybees set significantly more fruits than 
those which received no visits, indicating that honeybees are effective pollinators (Yang et al. 2007, Abdelgadir et al. 2009). Simple descriptions and relevant research reports on the floral structure of $J$. curcas could be found in Flora of China (Huang et al. 1997) and Flora of Guizhou (Li et al. 1992), yet the descriptions of the phenotypic traits for male and female flowers are not accurate or comprehensive. Besides, there have been no reports about the process on $J$. curcas from pollen germination stigma to pollen tubes conducting fertilization after entering the ovary and ovule. Therefore, this paper observed on the floral structure of $J$. curcas, which supplemented and rectified some existing descriptions about the floral structure in prior reports. Through experiment of artificial pollination and estimation of OCI, put forward the characters of $J$. curcas propagating system, which would fill up the blank of the research on pollen grains germinating after pollination, complemented the reproduction characters of $J$. curcas and provide theory foundation for taxonomy.

\section{MATERIALS AND METHODS}

All of the experiments were conducted for two years. Floral structure and pollination characteristics were observed in 2010 through field artificial pollination experiments as well as observation of prepared slides under the microscope. Field experiments were undertaken at Forestry Center of Luodian County, Guizhou Province, China. On this basis, pollen germination experiment was undertaken in 2011 through artificial pollination experiments by water-trainning in Forest Breeding Laboratory of Guizhou University, in Guiyang city Guizhou Province. The main methods were as follows:

Study site: This study was carried out in Forestry Center of Luodian County (25 $43^{\prime}$ '58' $\mathrm{N}-106^{\circ} 42^{\prime} 56^{\prime \prime}$ E) located in the South of Guizhou Province at $500 \mathrm{~m}$ in elevation, subtropical monsoon climate, annual average temperature was $20^{\circ} \mathrm{C}$, annual rainfall $1335 \mathrm{~mm}$.
Observation on the characteristics of $\boldsymbol{J}$. curcas flowers: The experiment materials were collected from the trees aged over four years, and flowers in different development stages were collected in May-June, 2010, which were put in the FAA Fixing Liquid (the ratio of formalin, glacial acetic acid and $70 \%$ of alcohol was 5:5:90) and taken back to the laboratory, undertaking dehydration, transparent treatment with xylene, embedding with paraffin, cuttings on LEICA RM 2015 microtome and observation and photo-taking under an OLYMPUS $\mathrm{C} \times 41$ microscope.

Male and female flowers of the inflorescence were collected, dissected for observation and photographed under a stereomicroscope, to describe the external characteristics of the male and female flowers.

Estimation of OCI (Outcrossing Index): Measurement of flower sizes and flowering behaviors as well as deduction of the breeding system was conducted according to Dafni (1992) Standard. The specific method was as follows: firstly, if the flower diameter was less than $1 \mathrm{~mm}$, mark it as 0 point; between $1-2 \mathrm{~mm}$, mark as 1 point; between $2-6 \mathrm{~mm}$, mark as 2 points; larger than $6 \mathrm{~mm}$, mark as 3 points. Secondly, concerning the time interval between anther cracking and stigma receptivity, simultaneous or pistil ripens first, mark it as 0 point. If stamen ripens first, mark as 1 point. Thirdly, concerning the spatial location of stigma and anther, if they are of a height, marked it as 0 point; if they are isolated spatially, mark as 1 point. The total of the above three is the OCI value. The standards for judgment are as follows: when OCI is 0 point, the breeding system is cleistogamy; when OCI is 1 point, the breeding system is obligate autogamy; when OCI is 3 points, the breeding system is of autogamy compatibility, and pollinators are needed sometimes; when OCI is 4 points, the breeding system is of partial autogamy compatibility, and pollinators are needed for outbreeding.

Observation on pollination characteristics: A batch of inflorescences, which will 
bloom, were collected in August 2011 and water-cultivated in the laboratory to understand the pollen germination, and artificial pollination was conducted to female flowers blooming: A) self-pollination: pollen was selected to pollinate the female flower of the same inflorescence. B) cross-pollination: pollen from inflorescences of different individual plants were selected to pollinate the female flowers of other individual plants, placed in an artificial climate box at a temperature of $35^{\circ} \mathrm{C}$, sampled regularly $1 \mathrm{hr}, 2 \mathrm{hr}$ or the like after pollination and then fixed by using FAA fixing liquid. The fixed material was then put into solution of $2 \mathrm{~N} \mathrm{NaOH}$, bathed in water for $30-40 \mathrm{~min}$, and then dyed in the solution of $0.25 \%(\mathrm{w} / \mathrm{v})$ Aniline Blue for $4 \mathrm{hrs}$. The pistil was then placed on the slide, pressed flat by cover glass, and then was observed through an Olympus fluorescence microscope.

Experiment of artificial pollination: To acquire detailed knowledge of the situation of pollination and fruit set, 90 inflorescences of $J$. curcas were randomly selected between MayJune in Forestry Center of Luodian County, of which the first 30 were bagged with castration, pollinated by using the pollen of other plants when their female flowers were in blossom; the next 30 bagged without castration, the female flowers were pollinated by the pollen of the same inflorescences; the rest 30 were not bagged without castration as contrast. The number of female flower of each inflorescence was recorded respectively, and about 30 days later the bags were removed and the number of fruit was surveyed. The fruit set rate $(\%)\left(R_{f}\right)$ was determined following: $R_{f}=\left(n_{1} / n_{2}\right) * 100$, where $n_{1}$ is the number of fruit and $n_{2}$ is the number of female flower per inflorescence.

The data obtained were handled with Microsoft Excel 2003 and analyzed for ANOVA using DPS7.05 (Data Processing System) software.

\section{RESULTS}

\section{Main characteristics of $\boldsymbol{J}$. curcas flowers:}

a) Inflorescence development: $J$. curcas flowers were of unisexuality and monoecism, dichasial inflorescences were mainly produced on the top of freshly-grown twigs (Fig. 1A), and insertion inflorescences were occasionally seen on the one-year-old branches. The inflorescence had a length of $6-12 \mathrm{~cm}$, lanceolate bracts could be found at its base with a length of 4-8cm, 5-11 secondary inflorescence axes (Fig. 1B) could be found on the main inflorescence axis, a bract could be seen at the base of each secondary inflorescence axes, which was in false dichotomous branching. In the development process, the top of the dichasial inflorescence stopped growing first and formed top flowers at the top, then the secondary inflorescence axes grew in succession, afterwards, tops of secondary inflorescence axes stopped growing to form top flowers, which appeared alternately with the growth of next-level lateral inflorescence axes, forming dichasial inflorescences eventually. Early inflorescence axes had a slow elongation growth and elongated accompany the growth of flower organs afterwards. Concerning the gradual elongation of inflorescence axes at all levels, inflorescence axes at the lower part generally outgrew those at the upper part (Fig. 1B), moreover, the more upward the position of the side inflorescence axis was, the smaller its length was and the larger concluded angle it had with the lord inflorescence axis. Eventually, only before florets came out did the flower stalk elongate.

b) Female flower characteristic: Female flowers originated from bisexuality (Fig. $1 \mathrm{C}-1 \mathrm{G})$. Initially, pistil and stamen in one flower grew simultaneously, and the stamen stopped growing during the process of development, thereby forming functional unisexual 

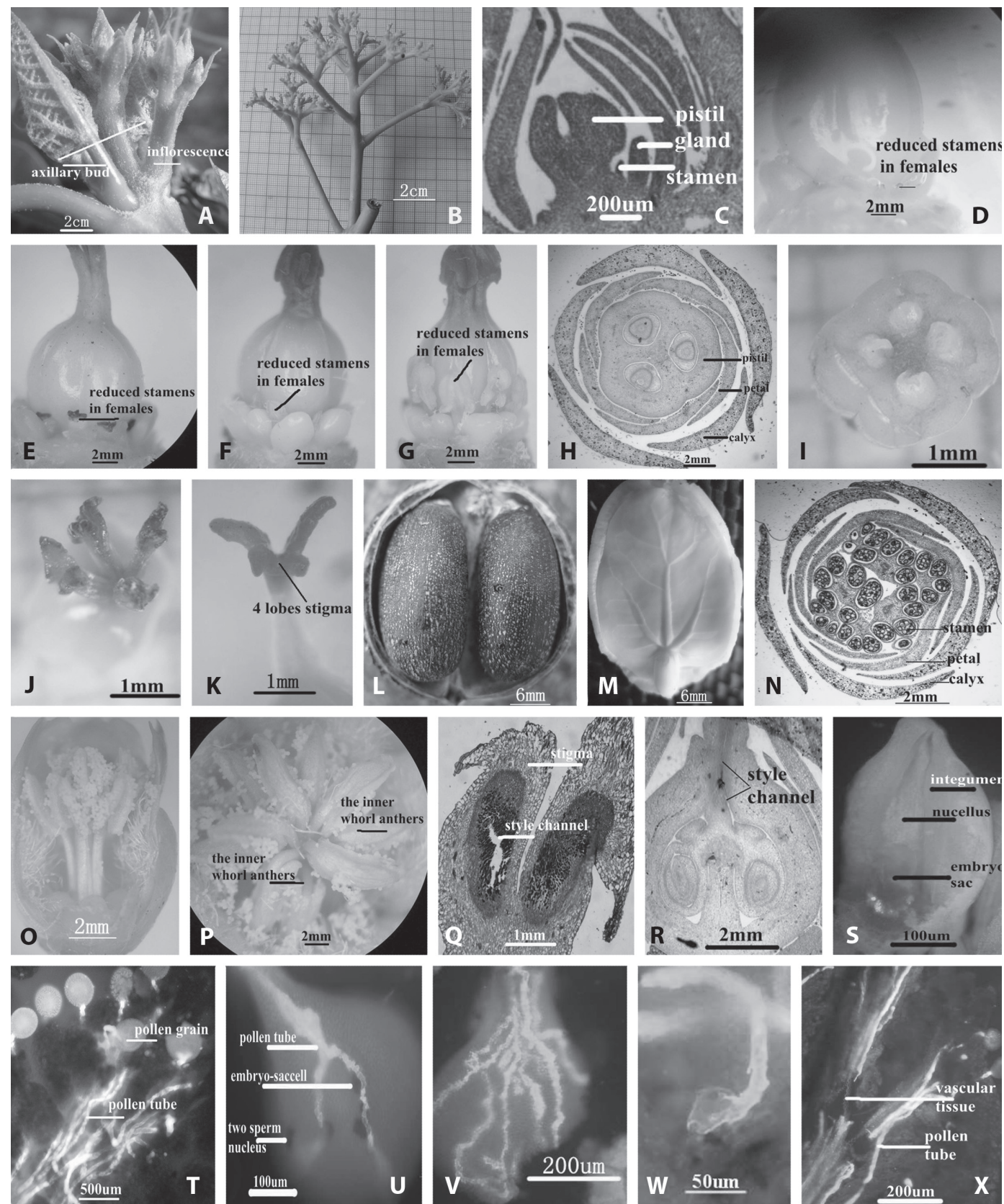

Fig. 1. A-X. Female floral and male floral architecture and pollen grains germinate(From left to right, from top to bottom): (A) Inflorescence on head of the branch; (B) Architecture of inflorescence without flower; (C) Female floral architecture shows and stamen emergence; (D-G) Vestigial degree of stamen in female floral; (H) Petals and calyxes arrangement in female flower; (I) ovary with 4 cells; (J) 4 styles of pistil with 4 cells ovary; (K) 4 lobes stigma; (L)Matured fruit and seeds; (M) Seed structure: show cotyledon; (N) Petals and calyxes arrangement in male flower; (O-P) anther arrangement and dehiscence; (Q) Stigma architecture; (R) Hollow stylar canal; (S) Ovule structure; (T) Pollens germinate on the stigma; (U) Pollen tube in ovule; (V) More than one pollen tubes enter ovule; (W) The intumescence and small hole in acropetal end of pollen tube; $(\mathbf{X})$ Pollen tube grow through stylar vascular tissue. 
flowers. Observation showed that the period of development arrest for stamens in female flowers was not unified. For some female flowers, their stamens stopped growing (Fig. 1C) when the top of their pistil concaved downward to form an ovary, and finally leaving a trace of stamens inside the female flower (Fig. 1D, 1E). For some stamens, they continued to grow along with the formation of ovaries and were forced to stop growing due to mature pistils or pollination eventually, and then stamens have been provided with the basic structure of male flower such as silk and anthers, but that pollen was not fully mature and did not have the ability of pollination (Fig. 1F, 1G).

Female and male flowers of $J$. curcas had five sepals in repeat imbricate arrangement and five petals in contorted arrangement respectively (Fig. 1H, 1N). The sepals were $1-2 \mathrm{~mm}$ beyond the bud top, coated with white fluff and the petals were pale yellow in color, and internal middle and lower parts coated with white fluff. The gland, five in number, was yellow in color (Fig. 1G), and ten stamens which have stopped growing (or a degenerated trace) were found inside the gland. The ovary was superior, orbicularovate, hairless and provided with 3-5 loculi (Fig. 1I: a 4-loculi ovary), and each loculus was provided with one ovule. The number of style was the same as that of cell, that was 3-5 (Fig. 1J: 4 stigmas), the base of the style was joined and the upper part was separated, each stigma was provided with 2-4 lobes, the stigma was V-shaped with two lobes but antlershaped (Fig. 1K, 4 lobes), that was, two longer ones and two shorter ones, in the case of four lobes. The capsule was of elliptic or spherical shape, $2.5-3 \mathrm{~cm}$ in diameter, yellow when mature while black when dry, its seed was 1.5$2 \mathrm{~cm}$ in length (Fig. 1L), black in color, provided with caruncle, the episperm was a black and fragile shell, the endothelium was white and membranous, and the endosperm was pulpy with two cotyledons wide and flat (Fig. 1M). Flowering period was April-November.

c) Male flower characteristic: The male flower was provided with five sepals and five petals respectively (Fig. 1N), and the calyx, with a length of around $4 \mathrm{~mm}$ and concrescent for the middle and lower part, was arranged in repeat imbricate arrangement. The petal was long circular, pale yellow-green in color, arrayed in a spiral way, and its middle and lower parts were coated with white fluff. The stamen was ten in number, the five exterior were distinct and the lower part of the internal thrum was concrescent. The anther was basifixed on the thrum and two-layered high and low. The five interior were at the top, the other five exterior were at the bottom, and they were arrayed in a criss-cross way and crack outwards longitudinally (Fig. 1O, 1P). The male flower was provided with five glands, yellow in color, apopetalous and arrayed with petals in alternate arrangement.

\section{Breeding system characteristics for $J$. curcas:}

a) Style structure and process of pollen germination: Observation showed that a single female stigma of a $J$. curcas was usually provided with 2-4 lobes and the surface of stigma was provided with many convexes and concaves (Fig. 1Q), which helped to adhere and embed pollen. The style was open and hollow (Fig. 1Q, 1R) with a passage provided inside. Pollen, after germination on the surface of stigma (Fig. 1T), penetrated the epidermic cells of stigma vertically. While passing through the hollow stylar passage, pollen tube traveled along the passage surface and grew among the materials secreted by the passage cells, (bunch-arrayed vascular tissues were provided inside the stylar passage (Fig. 1X), entered the ovary and then entered the embryo sac through micropyles. The pollen tube of $J$. curcas, uneven and cylinder-shaped, grew relying on its tail end. After grown to a certain length, materials contained in the original pollen would all gather at the front end of the pollen tube, causing the top to expand and then forming a round micropore at the top (Fig. $1 \mathrm{~W})$, so that sperm nucleus could be released out of the micropore for fertilization (Fig. 1U). 
Observation after pollination found that one or more pollen tubes entered the nucellus tissue (Fig. 1V) through the micropyle in succession, however, some pollen tubes would produce micropores during their elongation, and some others would produce micropores when elongating into the ovule, enter the embryo sac eventually and be discharged from the pollen tube of the reproductive cell, thus completing the fertilization. After entering the ovule (Fig. 1S), the pollen tube would produce more bends (Fig. 1U, 1V) modally, which was probably due to the fact that no special passage like that inside the style was provided inside the ovule and that pollen would have to reach the embryo sac only through intercellular space or cell walls.

b) Distribution characteristics and pollination tendency of flowers: The distribution characteristics and pollination medium of $J$. curcas flowers indicated that the breeding system of $J$. curcas was of self-pollination and cross-pollination. In general, a plant will choose pollen from another plant to complete fertilization, yet a selective abortion contains the fruit of self-pollen seeds to avoid inbreeding depression and improve the average quality and suitability of the later generation. Concerning the lack of pollen, the fruit of selffertilization will mature as well to ensure the reproduction of species. From table 1, it could be seen that the floral and pollination characteristics of $J$. curcas provided its breeding system with two tendencies, i.e. self-pollination and cross-pollination, which was the result of its long-term adaptation to nature.

c) Outcrossing index estimation: The OCI of $J$. curcas was measured according to Dafni (1992) standard as follows. The mean diameter of $J$. curcas flower was about $6-10 \mathrm{~mm}$, so marked as 3 points. In one inflorescence the pistil ripened first, marked as 0 point. The stigma and anther of $J$. curcas were isolated spatially, so marked as 1point. The total of the above was the OCI value, ie 4 points. The breeding system of $J$. curcas was of partial autogamy compatibility, and pollinators were needed for outbreeding, which was in agreement with the above observation and research of other aspects of $J$. curcas.

d) Result of pollen grains germination by different ways of pollination: The observation on pollen tube germination after pollination suggested that pollen germinated and grew very quickly on stigma of the flower itself as well as others, growing to the bottom of stylus within $1 \mathrm{hr}$, to ovary $2 \mathrm{hr}$, to ovule $4 \mathrm{hr}$, without notable differences.

Table 2 showed that pollen grains germinated rapidly after reaching stigma, that pollen tube grew to bottom of stigma within $1 \mathrm{hr}$, then went on to ovary, that pollen tube came into ovule through micropyle and reached embryo sac within $4 \mathrm{hr}$, and finally discharged sperm through the small hole on the top of pollen tube

TABLE1

Flowers characteristics and pollination tendency

\begin{tabular}{|c|c|c|}
\hline Characteristics & Autogamy & Allogamy \\
\hline Spatial position & $\begin{array}{l}\text { Male flowers in the middle and bottom part of } \\
\text { inflorescence, female flowers in the upper part. }\end{array}$ & $\begin{array}{l}\text { Unisexuality, spatial isolation between pistil } \\
\text { and stamen. }\end{array}$ \\
\hline Floret Florescence & $\begin{array}{l}\text { Flower synchronization happens to some inflo- } \\
\text { rescence. }\end{array}$ & $\begin{array}{l}\text { Female flower blossom first in some inflores- } \\
\text { cence, flowering asynchronism. }\end{array}$ \\
\hline Flowering phase & $\begin{array}{l}\text { Flower synchronization happens to male and } \\
\text { female flowers in the inflorescences of the same } \\
\text { plant. }\end{array}$ & $\begin{array}{l}\text { Flower synchronization happens to male and } \\
\text { female flowers among different plants. }\end{array}$ \\
\hline Kinds of pollinator & Ant & Flying insects. \\
\hline
\end{tabular}


TABLE 2

Result of pollen grains germinate by artificial pollination

\begin{tabular}{|c|c|c|}
\hline $\begin{array}{l}\text { Hours after } \\
\text { pollination }\end{array}$ & Autogamy & Allogamy \\
\hline $1 \mathrm{hr}$ & $\begin{array}{l}\text { Large amounts of pollen grains germinate on } \\
\text { stigma, with most of pollen tubes reaching to the } \\
\text { bottom of stigma, and a few pollen tubes appearing } \\
\text { at the top of ovary. }\end{array}$ & $\begin{array}{l}\text { Large amounts of pollen grains germinate on stigma, } \\
\text { with most of pollen tubes reaching to the bottom of } \\
\text { stigma, and a few pollen tubes appearing at the top } \\
\text { of ovary. }\end{array}$ \\
\hline $2 \mathrm{hr}$ & $\begin{array}{l}\text { Some of the stigmas begin to enter into ovary. } \\
\text { Fluorescence of pollen tubes can be seen on the } \\
\text { upper part of a few ovules. }\end{array}$ & $\begin{array}{l}\text { Some of the pollen tubes grow into ovary through } \\
\text { stylus. }\end{array}$ \\
\hline $4 \mathrm{hr}$ & Pollen tubes grow into ovule. & Pollen tubes enter into ovule and embryo sac. \\
\hline $10 \mathrm{hr}$ & Many pollen tubes exist in ovule at the same time. & $\begin{array}{l}\text { Some pollen tubes still grow towards ovary. Nucleus- } \\
\text { like substance still can be seen in pollen tubes. }\end{array}$ \\
\hline $18 \mathrm{hr}$ & $\begin{array}{l}\text { Pollen grains and tubes in stigma and stylus } \\
\text { decrease. }\end{array}$ & $\begin{array}{l}\text { In embryo sac, pollen grains and tubes on stigma and } \\
\text { stylus decrease. }\end{array}$ \\
\hline
\end{tabular}

to get fertilized. Pollen grains and pollen tubes in stigma and stylus began to decrease at the 18th hour after pollination.

\section{e) Experiment on artificial pollination:} Investigation on fruit setting rate of artificial pollination showed (Table 3): fruit setting rate of self-pollination was $77.38 \%$, fruit setting rate of cross-pollination was $79.00 \%$, fruit setting rate of natural pollination was $80.51 \%$.

There was no marketable differences among the fruit setting rates of the three ways of pollination, with natural pollination rate a little higher than cross-pollination, crosspollination than self-pollination. The fruit setting rate of artificial pollination was a little bit lower than natural pollination for the reason that fruit bagging resulted in the weakening of sunlight, which was harmful to fruit setting. It also showed that pollination of $J$. curcas was adequate under natural conditions.

\section{DISCUSSION}

Both Flora of China (Huang et al. 1997) and Flora of Guizhou (Li et al. 1992) described inflorescence of $J$. curcas as axillary. However, the author of the paper observed that the inflorescence of $J$. curcas germinated from the top of branch, with the upper end of the branch stopping growing upward because of the formation of inflorescence. After a span of time, 1-3 (usually 2) lateral buds under inflorescence germinated, taking place of bough growing upward, which looked like inflorescence grew from the body of branch, leading to the false conclusion that inflorescence of $J$. curcas was

TABLE 3

Mean values for the number of female flower and fruit and the fruit set rate of the artificial pollination experiments

\begin{tabular}{lccc} 
& Female & Fruit & Fruit setting rate \\
Allogamy & $5.2759 \pm 2.8896 \mathrm{a}$ & $4.2414 \pm 2.5587 \mathrm{a}$ & $78.9956 \pm 26.1002 \mathrm{a}$ \\
Autogamy & $5.5862 \pm 3.2570 \mathrm{a}$ & $4.0345 \pm 1.9907 \mathrm{a}$ & $77.3756 \pm 19.9821 \mathrm{a}$ \\
Natural pollination & $5.2069 \pm 2.6777 \mathrm{a}$ & $4.4483 \pm 3.0306 \mathrm{a}$ & $80.5090 \pm 34.4626 \mathrm{a}$ \\
\hline
\end{tabular}

The results were measured by mean $\pm \mathrm{SD}$, Values in the same column followed by the same letter do not differ significantly by the Duncan Test $(\mathrm{p}>0.05)$ or ANOVA $(\mathrm{p}>0.05)$. 
axillary. It was in agreement with the opinion of Yang et al. (2008) and Xie et al. (2009).

Most of female flowers of $J$. curcas had 3-loculi ovary, but some of them even had ovary with four or five loculi, which also happened to other species of Jatropha. Stigma and ovary were same in number, with each stigma having 2-4 lobes. However, both Flora of China (Huang et al. 1997) and Flora of Guizhou (Li et al. 1992) described as "ovary has three loculi and 2 lobes at the head of each stigma", which was incomplete.

As to the arrangement of sepals and petals of J. curcas, Flora of China (Huang et al. 1997) and Flora of Guizhou (Li et al. 1992) described J. curcas as imbricate. Li et al. (2007) found that sepals of male flowers were in imbricate arrangement, however, researched on the slice in this paper showed that sepals both in male and female flowers were in repeat imbricate arrangement, with petals in rotating pattern.

$J$. curcas began to geminate inflorescence in April after new branches gave birth to 5-8 new leaves. Productive grew and vegetative grew appear by turns, with several flowering phase each year. $J$. curcas in Luodian had two mass flowering in a year, and the blooming period lasted to October or November. Yang et al. (2007) found that J. curcas's flowering period lasted to late November in Menglun of Xishuangbanna. Hence, flowering phase of $J$. curcas should range from April to November, which was not in concordance with "flowering phase September-October" in Flora of China (Huang et al. 1997) and "flowering phase AprilMay" in Flora of Guizhou (Li et al. 1992).

Generally speaking, pollen tube enters into blastula through a synergid, and the synergid will disintegrate after that. And pollen tube will release contents at the location of the synergid. However, in my study, there were two even more pollen tubes were seen in blastula after pollination. Pollen tubes did not enter into blastula directly but through the base of it after grew into nucellus. There was no synergid at the place where two sperms were released after several pollen tubes entered into blastula. Therefore, the process of federalization and the action of pollen tube after entering to blastula required further research.

Lu et al. (2008) believed that stigma of female flower could secrete mucus and had many small holes on it, easily to stick pollen grains carried by insect, which showed that stigma of $J$. curcas was wet. Luo et al. (2007) found that there was no notable secreting substance, which proved that stigma of $J$. curcas was dry. The research conducted in this paper showed that the surface of stigma glows after flowering, which looked like there was secreting substance, but observation on slice showed that stigma didn't have secreting gland. Therefore, whether $J$. curcas's stigma is wet or not needs further research.

In addition, according to Yang et al. (2007), fruit-bearing rate was 0 if they emasculation and bagging it by parchment bag to segregate pollinators before flowering. However, according to Li et al. (2007), fruit-bearing rate was $12 \%$ by the same method. Therefore, they believed that $J$. curcas belongs to apomixis plant. The authors found that there were large numbers of antes on the plant under discussion; was it effective enough to segregate antes as pollinators by bagging in Li's experiments ( $\mathrm{Li}$ et al. 2007)? Whether $J$. curcas is apomixes or not, which still lack sound proof and cry for further study.

\section{ACKNOWLEDGMENTS}

The work was supported by of Major Project of Guizhou province: Project number 20076004-5, Natural Science Foundation of Guizhou province: Project number J(2010)2048, Guizhou Science and Technology Department, the People's Republic of China and doctor fund project: Project number 20070657001, Ministry of Education, the People's Republic of China. The authors thank Yang Lixia from Sanmenxia Foreign Language Primary School, Sanmenxia, China and Marcus Ching from University of California, USA, for their valuable help in English grammar at sentence. 


\section{RESUMEN}

Jatropha curcas pertenece a la familia Euphorbiaceae, y es una importante especie arbórea para la producción de diesel. Las descripciones actuales de los rasgos fenotípicos de flores masculinas y femeninas no son exhaustivas y no hay informes sobre la germinación del polen en el estigma, que viaja a través de los tubos polínicos hasta el ovario y se de la fertilización de los óvulos de J. curcas. Para evaluar esto, se llevaron a cabo experimentos para estudiar la biología reproductiva de $J$. curcas en la provincia de Guizhou, Guiyang, China. La estructura floral y el proceso de germinación de polen se describen en detalle y se determinó el sistema reproductivo. Los resultados mostraron que las flores de $J$. curcas eran a la vez unisexuales y monoicas, la floración se dio entre abril y noviembre. Las flores femeninas y masculinas tienen cinco pétalos en disposición retorcida y cinco cálices en disposición imbricada. La flor femenina originada de flores bisexuales finalmente formo flores unisexuales, cuando el estambre ceso el crecimiento en un período diferente. El pistilo tuvo 3-5 estilos, unidos en la base y separados en 3-5 estigmas en la parte superior. Cada estigma tenía de 2-4 lóbulos. Los estilos eran huecos. El polen germinado en la superficie del estigma, se transporta a través de los tejidos vasculares, que se disponen en haces, y finalmente son canalizados a través del micrópilo para entrar a la blástula. El tubo polínico tenía forma de cilindro irregular largo. El extremo superior del mismo se hincho y formó un pequeño agujero redondo con el fin de liberar los núcleos de esperma mientras que el tubo de polen crecía y se extendía. Estimaciones del índice de cruzamiento y experimentos de polinización artificial indicaron que $J$. curcas era capaz tanto de auto-polinización como de polinización cruzada. La velocidad de germinación del polen en el estigma no difiere mucho entre una planta con autopolinización y otra con polinización cruzada, y el polen de dos fuentes diferentes podría alcanzar el ovario en un día. Tanto la prueba de polinización artificial como el índice de cruzamiento indicaron que: J. curcas tiene tanto sistemas de autopolinización como de polinización cruzada.

Key words: Jatropha curcas, estructura floral, polinización artificial, germinación de polen, sistemas de crianza.

\section{REFERENCES}

Abdelgadir, H.A., S.D. Johnson \& J. Van Staden. 2008 Approaches to improve seed production of $J$. curcas L. SAAB Annu. Meet. Abst. 359.

Abdelgadir, H.A., S.D. Johnson \& J. Van Staden. 2009. Pollinator effectiveness, breeding system, and tests for inbreeding depression in the biofuel seed crop, $J$. curcas. J. Hortic. Sci. Biotech. 84: 319-324.

Bhattacharya, A., K. Datta \& S.K. Datta. 2005. Floral biology, floral resource constraints and pollination limitation in J. curcas L. Pak J. Biol. Sci. 8: 456-460.

Dafni, A. 1992. Pollination ecology: a practical approach. Oxford University, Oxford.

Huang, C.J., B.X. Huang \& L.Y. Xu. 1997. Flora of China. Sci., Beijing, Beijing, China.

Li, K., W.L. Yin \& C.W. Luo. 2007. Breeding System and Pollination Ecology in J. curcas. Forest Res. 20: 775-781.

Li, Y.K., W.L. Huang, X.G. Wang, X.S. Zhang \& J.R. Wu. 1992. Flora of Guizhou. Guizhou people's Publishing House, Guiyang, China.

Lu, J.H., J. Wu, K. Xiao \& L. Tang. 2008. Studies on the relation between the structures of flowers and pollination in J. curcas. J. Sichuan Univ. (Nat. Sci. Edi.). 45: 1485-1488.

Luo, C.W., K. Li, Y. Chen, Y.Y. Sun \& W.Y. Yang. 2007. Pollen viability, stigma receptivity and reproductive features of $J$. curcas L. (Euphorbiaceae). Acta Bot. Borea1-Occident. Sin. 27: 1994-2001.

Xie, W.W., F.R. Lin, Y. Xu, S.H. Wang \& F. Chen. 2009. Investigation on the breed ing indexes of $J$. curcas L. J. Anhui Agr. Univ. 36: 387-392.

Yang, Q., D.P. Peng, Z.B. Duan, Z.L. Wang \& Q.X. Sun. 2007. Study on Pollination Biology of J. curcas (Euphorbiaceae). J. South China Agr. Univ. 28: 62-66.

Yang, Q., D.P. Peng, Z.B. Duan, Z.L. Wang, Q.X. Sun \& Z.H. Peng. 2008. Floral biology of Jatropha curcas. J. Fujian Col. Forest. 28: 52-55. 
